\title{
MAGT1 Gene Mutation
}

National Cancer Institute

\section{Source}

National Cancer Institute. MAGT1 Gene Mutation. NCI Thesaurus. Code C157579.

A change in the nucleotide sequence of the MAGT 1 gene. 